\title{
The Influence of Transformational Leadership and Interpersonal Communication on Teachers' Performance
}

\author{
Ade Melianah 1, Matin 2, Heru Santosa 3 \\ DOI: 10.35445/alishlah.v13i1. 574
}

\begin{tabular}{|c|c|}
\hline Article Info & Abstract \\
\hline $\begin{array}{l}\text { Keywords: } \\
\text { Transformational } \\
\text { leadership } \\
\text { Interpersonal } \\
\text { communication } \\
\text { Teachers'performance }\end{array}$ & $\begin{array}{l}\text { This research intends to observe how transformational leadership and } \\
\text { interpersonal communication affect teachers' performance at the State } \\
\text { Vocational High School of East Jakarta II. Researchers use the survey to collect } \\
\text { quantitative data and multiple regression. Using the Slovin technique and } \\
\text { closed-questionnaire, the researcher got } 78 \text { teachers of } 353 \text { people to become } \\
\text { the research sample. The hypothesis is obtained from the t-test and F-test. The } \\
\text { result shows that transformational leadership and teachers' performance have } \\
\text { a positive and significant effect, which means that the principals' roles } \\
\text { substantially improve teachers' performance. Interpersonal communication } \\
\text { and teachers' performance also have positive and significant effects. It means } \\
\text { that communication between principal and teachers' can have a significant } \\
\text { impact on teachers' performance. Transformational leadership and } \\
\text { interpersonal communication have a positive and significant effect with a } \\
\text { coefficient of determination of o.205 or } 20.5 \% \text {, meaning that transformational } \\
\text { leadership and interpersonal communication contribute to an increase in } \\
\text { teacher performance of } 20.5 \% \text {. }\end{array}$ \\
\hline
\end{tabular}

Kata kunci:

Kepemimpinan

Transformasional

Komunikasi

interpersonal

Kinerja guru

\begin{abstract}
Abstrak
Tujuan penelitian ini adalah untuk mengetahui apakah kepemimpinan transformasional dan komunikasi interpersonal memiliki pengaruh yang positif dan signifikan secara simultan terhadap kinerja guru Sekolah Menengah Kejuruan Negeri Jakarta Timur II. Metode dalam penelitian ini menggunakan survey dengan pendekatan kuantitatif dan teknik regresi linear berganda. Populasi pada penelitian ini adalah 353 guru dengan menggunakan teknik sampel Slovin dengan tingkat kesalahan 10\% sehingga didapat sampel sebesar 78 guru. Instrumen penelitian ini menggunakan angket tertutup berdasarkan skala likert. Pengujian hipotesis dilakukan berdasarkan uji-t,ujiF, dan Uji koefisien determinasi. Hasil penelitian menunjukkan bahwa kepemimpinan transformasional dan kinerja guru berpengaruh positif dan signifikan, artinya peran kepala sekolah sangat penting dalam peningkatan kinerja guru, Komunikasi interpersonal dan kinerja guru berpengaruh positif dan signifikan, artinya komunikasi antar atasan dan bawahan dapat mempengaruhi hasil dari kinerja guru. Kepemimpinan dan komunikasi interpersonal berpengaruh positif dan signifikan dengan nilai koefisien determinasi sebesar 0,205 atau 20,5\%, artinya kepemimpinan
\end{abstract}

\footnotetext{
${ }^{1}$ State University of Jakarta, Jakarta, Indonesia

Email: ademelianah@gmail.com

2 State University of Jakarta, Jakarta, Indonesia

Email: Mpo18matinpasca@gmail.com

3 State University of Jakarta, Jakarta, Indonesia

Email: hrsnts@yahoo.com
} 
transformasional dan komunikasi interpersonal secara bersama-sama memberikan kontribusi terhadap peningkatan kinerja guru sebesar 20,5\%.

\section{INTRODUCTION}

Promoting the nation's intellectual life is the ultimate goal of education in our country and developing Indonesian people as a whole. It is formed by the divinity of the one true God. It has a high character, knowledge and skills both physically and mentally healthy, and a solid and independent personality and social and national responsibility. Having an education will make a person compete, complete, and motivate oneself to be better in life. The government has provided education from elementary level to tertiary education. It should be done and managed continuously. According to Law No. 20 in 2003 about National Education System (Sisdiknas), education should develop and enhance students potency to have the proper root to be competent, creative, independent, democratise, and responsible as citizens. They are expected to adopt for the time being based on local belief and culture. The system is integrated to achieve national education goals. The leadership style will determine to what extent the leadership shows its effectiveness because a good leader will realise and achieve it. (Yukl, 2013) define that transformational leadership is: (a) influencing idealism, (b) paying attention to each individual, c) motivating and inspiring, and (d) encouraging and stimulating intellectuality.

A must-have skill for principals is to have managerial competence, carry out their duties, and lead the organisation. This managerial competence requires demands the school principles to do their job effectively and efficiently. At the same time, the educator must have interpersonal communication, attitude, pedagogical competence and discipline in teaching to reach the learning objectives. The regulation of National Education No. 13 in 2007 about Principle Standards for Schools/Madrasah explains five competencies for school principals: personality, managerial, entrepreneurship, supervision, and social competencies. School principles should be qualified to be a navigator who leads and helps teachers achieve the school objectives.

According to Masa'deh et al. (2016), teachers' performance can be measured using several ways: job quality, timeliness, performance, productivity, training effectiveness, appraisals, work results, behaviour, and personal characteristics. Furthermore (Yang \& Hwang, 2014) suggested that teachers' performance is related to an interaction involving three main factors: skills, effort, and the nature of working conditions. In addition, teachers' performance in a role refers to teachers' behaviour that contributes to the technical performance of the organisation. Task performance is considered an essential component of job performance that assesses individuals who contribute to the organisation's technical core.

Each school has its demands on teachers at work. A teacher's performance can carry out his/her duties under predetermined objectives covering planning, implementing the lesson plan and teaching-learning process, creating and maintaining optimal classrooms, controlling good learning conditions, and assessing learning outcomes. Therefore, work quality is the main thing in determining a teacher's performance. To maximise teachers' performance, writers need to investigate the factors that may influence this study. Theoretically and based on relevant studies, it can be seen that many factors can affect performance, including transformational leadership and interpersonal communication.

According to Doh et al. (2011: 98), the definition of leadership varies from person to person. The leader is defined as a person who holds a significant position in a group, persuades others regarding the job's expected position, and organises and directs the group in sustaining itself and reaching its purpose. The leadership of the principal is crucial in succeeding each institution. In carrying out their mandate, teachers need guidance and supervision from leaders, especially school principals, to work optimally. Through the role of the leader as an educator, a leader can provide encouragement, ideas, and various information to add insight and knowledge to the teacher as the primary basis for improving the competence of his/her duties. Concerning the previous statement 
(Colquitt et al., 2017), transformational leadership involves followers who are inspired to commit to a shared vision to give meaning to their work while also being an example for others to develop potential and see their own problems from a new perspective.

Transformational leadership is one of the most popular theories and is essential in leadership in leading an organisation. Transformational leadership affects one's performance very well. Robbins \& Judge (2017) says a transformational leader can inspire subordinates/followers to go beyond self-interest. A leader can have a profound and extraordinary effect on subordinates/followers. It is the same with the research conducted by Ocham \& Okoth (2015). The research found that the principal strongly influences in increasing teacher performance and how a principal direct his team. In this case, teachers have to improve quality and professionalism in the teaching and learning process by introducing teaching staff, joint leadership strategies, staff development, new teachers recruitment, evaluation of teacher support, recommendations, promotions, or incentives. Jyoti \& Bau (2015) state that transformational leadership and job performance are higher education studies.

Regarding those relevant studies, this study only discusses transformational leadership affecting performance and elaborates how communication between colleagues improves teacher performance. Research conducted by Crede et al. (2019) entitled "The generalizability of transformational leadership across cultures: a meta-analysis" was conducted to determine the effect of transformational leadership and employee performance. The sample used in the study was 215 employees from 34 countries. The results directly influenced transformational leadership on employee performance in several developed countries such as Western Europe and North America.

Human is social creatures, and it affects how principals will interact with teachers. It also affects the working environment to know what to like and dislike in working colleagues' preferences. Interpersonal communication is deeply valued to engage a good communication in life. Communication is a concept of telling, exchanging ideas or thoughts to enrich information, and giving critics a harmonious working environment. Robbins \& Judge (2013) Interpersonal communication is exchanging meaning from one to another. There are eight elements of interpersonal communication: source of communication (sender), message, encodes, lines decodes, listener/receiver, noise and feedback. The sender starts to encode his/her messages. This study has supported Jalalkamali et al. (2016); communication is considered an effective reaction when both sender and listener agree on its message and concept. Hence, this study reveals that communication is a prior variable on teachers' performance. It creates intimacy, nearness, and deeper understanding between the principal and his team, allowing them to cooperate better. It emphasised exchanging feelings or showing care to each other.

This research focuses more on the transformational leadership of the principals of the State vocational high schools in East Jakarta II. In contrast, the researchers do not examine other leadership styles in various principal leadership styles such as authentic, transactional, democratic, autocratic, laissez-faire. The interpersonal communication variable is the independent variable between the influence of each variable. It focuses on the performance of teachers in schools. This study was conducted to show that transformational leadership and interpersonal communication can affect teacher performance based on findings and facts. The results of this study are expected to be useful in understanding what principals need to prepare in leading, managing, regulating, and making interpersonal communication between principals and teachers and between teachers smooth. There is no misunderstanding of the communication delivered to prevent teachers' decreased performance in schools. Principals must be able to create conducive and smooth communication to support improving teacher performance because the presence of teachers is significant in the continuity of education in schools.

\section{METHOD}

This study uses a quantitative approach with a path analysis model. The slovin formula obtained the research sample with an error rate of $10 \%$. The research sample was 78 teachers at The 
State Vocational High School Teachers of East Jakarta II with a proportional random sampling technique (Sugiyono 2017). The instrument was distributed to each respondent and previously been tested with validity and reliability tests. This research was conducted by distributing a closed questionnaire that contains statements and alternative answers in the google form application. The questionnaire consists of 40 statements about the independent variables. It includes 40 statements of transformational leadership and 40 interpersonal communication variables, while the dependent variable was 40 statements of teachers' performance. So, there are 120 statements on the questionnaire. This study has several prerequisite tests for path analysis: normality test, significance test, linearity test, multicollinearity test, heteroscedasticity test, correlation coefficient test, and ttest. The model used the path analysis to determine variables X1 and X2 on the Y test variable. Then, the hypothesis will be carried out using the t-test and F-test to determine the effect between variables partially or simultaneously. This model will also use coefficient determination because this value shows how much influence the independent variable has on the dependent variable. The application used to perform statistical calculations in this study is SPSS version 25.

\section{FINDINGS AND DISCUSSION}

\section{Analysis Of Prerequisite Test}

1) Normality Test

By doing a normality test using the SPSS 25 version with Kolmogorov Smirnov, it can see from the table that the result of Asymp-Sig (2-tailed) is 0.058.

Table 1. Normality Test Kolmogorov Smirnov

\begin{tabular}{llr}
\hline & & \multicolumn{2}{c}{$\begin{array}{c}\text { Unstandardized } \\
\text { Residual }\end{array}$} \\
\hline $\mathrm{N}$ & Mean & 78 \\
Normal Parameters & a,b & .0000000 \\
& Std. & 9.13397607 \\
& Deviation & .099 \\
Most Extreme Differences & Absolute & .068 \\
& Positive & -.099 \\
& Negative & .099 \\
Test Statistic & & $.058^{\mathrm{c}}$ \\
\hline
\end{tabular}

Based on the calculation, it is obtained that Asymp.Sig. (2tailed) is $0.058(>) 0.05$, the data is categorised as a normal distribution.

2) Significance and Linearity Test

It is intended to prove that there is a significant relationship between the independent variable and the dependent variable in the study. There are two independent variables, transformational leadership (X1) and interpersonal communication (X2) and one dependent variable, teachers' performance $\left(\mathrm{X}_{3}\right)$. The following result was obtained:

Table 2. Linearity Test: Transformational Leadership on Teacher Performance

\begin{tabular}{|c|c|c|c|c|c|c|c|}
\hline & & & $\begin{array}{c}\text { Sum of } \\
\text { Squares }\end{array}$ & $\mathrm{df}$ & $\begin{array}{c}\text { Mean } \\
\text { Square }\end{array}$ & $\mathrm{F}$ & Sig. \\
\hline $\begin{array}{l}\text { Performance }\left(\mathrm{X}_{3}\right) * \\
\text { Transformation }\end{array}$ & $\begin{array}{l}\text { Between } \\
\text { Groups }\end{array}$ & (Combined & 4538.414 & 32 & 141.825 & 1.800 & .034 \\
\hline \multirow[t]{4}{*}{ Leadership (X1) } & & Linearity & 1132.780 & 1 & 1132.780 & $\begin{array}{r}14.38 \\
0\end{array}$ & .000 \\
\hline & & $\begin{array}{l}\text { Deviation } \\
\text { from } \\
\text { Linearity }\end{array}$ & 3405.634 & 31 & 109.859 & 1.395 & .152 \\
\hline & Within Groups & & 3544.881 & 45 & 78.775 & & \\
\hline & Total & & 8083.295 & 77 & & & \\
\hline
\end{tabular}

The result shows that the significance value of transformational leadership (X1) to the teachers' performance $\left(\mathrm{X}_{3}\right)$ is 0,152 . Because $0.152>0,05$, it can be concluded that there is a linear relationship between variable $\mathrm{X}_{1}$ and $\mathrm{X}_{3}$. 
Table 3. Linearity Test: Interpersonal Communication on Teacher Performance

\begin{tabular}{|c|c|c|c|c|c|c|c|}
\hline & & & $\begin{array}{c}\text { Sum of } \\
\text { Squares }\end{array}$ & $\mathrm{df}$ & $\begin{array}{l}\text { Mean } \\
\text { Square }\end{array}$ & $\mathrm{F}$ & Sig. \\
\hline \multirow{6}{*}{$\begin{array}{l}\text { Performance }\left(\mathrm{X}_{3}\right) \\
\text { * Communication } \\
\text { (X2) }\end{array}$} & \multirow{4}{*}{$\begin{array}{l}\text { Between } \\
\text { Groups }\end{array}$} & (Combined) & 4367.095 & 44 & 99.252 & .8 & \multirow[t]{2}{*}{.656} \\
\hline & & & & & & & \\
\hline & & Linearity & 965.947 & 1 & 965.947 & 8.578 & .00 \\
\hline & & $\begin{array}{l}\text { Deviation from } \\
\text { Linearity }\end{array}$ & 3401.147 & 43 & 79.096 & .702 & .863 \\
\hline & \multicolumn{2}{|c|}{ Within Groups } & 3716.200 & 33 & 112.612 & & \\
\hline & \multicolumn{2}{|l|}{ Total } & 8083.295 & 77 & & & \\
\hline
\end{tabular}

The result shows that the correlation between the interpersonal communication variable (X2) on the teachers' performance variable $\left(\mathrm{X}_{3}\right)$ is 0,863 . Because $0.863>0.05$, it can be concluded that there is a linear relationship between $\mathrm{X}_{2}$ and $\mathrm{X}_{3}$.

3) Multicollinearity Test

Multicollinearity is used to determine whether there is a correlation between the independent variable (Transformational Leadership, Interpersonal Communication) and the dependent variable (Teachers' Performance). A good regression model is a model that does not have symptoms multicollinearity with value tolerance $>0.10$ and $\mathrm{VIF}$ value $<10,00$. The following result was obtained:

Table 4. Multicollinearity Test

\begin{tabular}{|c|c|c|c|c|c|c|c|c|}
\hline \multirow{2}{*}{\multicolumn{2}{|c|}{ Model }} & \multicolumn{2}{|c|}{$\begin{array}{l}\text { Unstandardised } \\
\text { Coefficients }\end{array}$} & \multirow{2}{*}{$\begin{array}{l}\text { Standardis } \\
\text { ed } \\
\text { Coefficient } \\
\text { s } \\
\text { Beta }\end{array}$} & \multirow[t]{2}{*}{$\mathrm{t}$} & \multirow[t]{2}{*}{ Sig. } & \multicolumn{2}{|c|}{$\begin{array}{l}\text { Collinearity } \\
\text { Statistics }\end{array}$} \\
\hline & & B & Std. Error & & & & $\begin{array}{l}\text { Toleran } \\
\text { ce }\end{array}$ & VIF \\
\hline \multirow[t]{3}{*}{1} & (Constant) & 80.586 & 16.107 & & 5.003 & .000 & & \\
\hline & $\begin{array}{l}\text { Transformation } \\
\text { Leadership (X1) }\end{array}$ & .284 & .100 & .304 & 2.845 & .006 & .929 & 1.076 \\
\hline & Communication (X2) & .194 & .078 & .265 & 2.479 & .015 & .929 & 1.076 \\
\hline
\end{tabular}

From the result, it can be seen that the tolerance value is $0.929>0.10$. Therefore, it means that there are no symptoms of multicollinearity in this study. In addition, decision-making can also be done by looking at the VIF. Because the VIF value is $1.076>10.00$, it can be concluded that there are no symptoms of multicollinearity in this research model.

4) Heteroscedasticity Test

Heteroscedasticity is used to determine whether a regression model has variant value fixed residual from one observation to another. The heteroscedasticity test in the study uses the Rank Spearman test based on decision making if the value is significant or sig. (2-tailed). It is greater than 0.05 , which indicates there is no problem with heteroscedasticity. After calculating using SPSS version 25, the following result was obtained:

Table 5. Heteroscedasticity Test

\begin{tabular}{|c|c|c|c|c|c|c|}
\hline & & \multicolumn{2}{|c|}{$\begin{array}{l}\text { Unstandardised } \\
\text { Coefficients }\end{array}$} & \multirow{2}{*}{$\begin{array}{c}\text { Standardise } \\
\mathrm{d} \\
\text { Coefficients } \\
\text { Beta } \\
\end{array}$} & \multirow[t]{2}{*}{$\mathrm{t}$} & \multirow[t]{2}{*}{ Sig. } \\
\hline & & B & Std. Error & & & \\
\hline \multirow[t]{3}{*}{1} & (Constant) & 17.731 & 9.464 & & 1.874 & .065 \\
\hline & $\begin{array}{l}\text { Transformation } \\
\text { Leadership (X1) }\end{array}$ & -.002 & .059 & -.004 & -.037 & .970 \\
\hline & Communication (X2) & -.073 & .046 & -.187 & -1.586 & .117 \\
\hline
\end{tabular}

Based on the table above, it can be that the sig. (2-tailed) value for transformational leadership is 0.970 , which is greater $(>)$ than 0.05 . Then the Sig. (2-tailed) for the interpersonal communication 
is 0.117 , which is greater $(>)$ than 0.05 . Because the two significance values obtained are greater than 0.05 , it can be concluded that there is no heteroscedasticity problem.

5) Correlation Test

Table 6. Correlations Test

\begin{tabular}{cccc}
\hline \multirow{2}{*}{ Matrix } & \multicolumn{3}{c}{ Co-efficient Correlation } \\
& $\mathrm{X}_{3}$ & $\mathrm{X}_{1}$ & $\mathrm{X}_{2}$ \\
\hline $\mathrm{X}_{3}$ & 1 & 0,374 & 0,346 \\
$\mathrm{X}_{1}$ & 0,374 & 1 & 0,266 \\
$\mathrm{X}_{2}$ & 0,346 & 0,266 & 1 \\
\hline
\end{tabular}

From the result, it can be seen that the correlation between interpersonal communication and transformational leadership r12 is 0.266 . The correlation between transformational leadership and teachers' performance $\mathrm{r} 13$ is 0.374 , the correlation between interpersonal communication and teachers' performance r23 is 0.346 .

\section{Multiple Linear Regression Analysis}

After using SPSS version 25 search for multiple linear regression models for this study, the following results were obtained:

Table 7. Multiple Linear Regression Analysis

\begin{tabular}{|c|c|c|c|c|c|c|}
\hline \multirow{2}{*}{\multicolumn{2}{|c|}{ Model }} & \multicolumn{2}{|c|}{ Unstandardised Coefficients } & \multirow{2}{*}{$\begin{array}{c}\begin{array}{c}\text { Standardised } \\
\text { Coefficients }\end{array} \\
\text { Beta } \\
\end{array}$} & \multirow[t]{2}{*}{$\mathrm{t}$} & \multirow[t]{2}{*}{ Sig. } \\
\hline & & B & Std. Error & & & \\
\hline \multirow[t]{3}{*}{1} & (Constant) & 80.586 & 16.107 & & 5.003 & .000 \\
\hline & $\begin{array}{l}\text { Transformation } \\
\text { Leadership (X1) }\end{array}$ & .284 & .100 & .304 & 2.845 & .006 \\
\hline & Communication (X2) & .194 & .078 & .265 & 2.479 & .015 \\
\hline
\end{tabular}

From these results, it can be concluded that the regression equation model in this study is: $\mathrm{X}_{3}=80.586+0,284+0,194$. Then, it also has the value of the coefficient of determination from this equation:

Table 8. Coefficient of Determination Value

\begin{tabular}{ccccccc}
\hline \multirow{2}{*}{ Variable } & rxixj & Pij & Direct Effect & Indirect Effect & X1 & R2 \\
\hline X1 & 0,266 & 0,304 & 0,093 & 0 & 0,021 & 0,114 \\
X2 & & 0,265 & 0,070 & 0,021 & 0 & 0,091 \\
& & & & & 0,021 & 0,205
\end{tabular}

Based on the table above, it can be seen that the direct influence between endogenous variables got a value of 0.093 for the influence of transformational leadership variables; meanwhile, the direct influence of interpersonal communication variables was 0.070. It means that the direct influence of transformational leadership is greater than the influence of interpersonal communication. Meanwhile, the effect through the correlative relationship of other exogenous variables can be seen from the indirect effect obtained from the variables of transformational leadership (X1) and interpersonal communication (X2) on teacher performance (Y) of 0.021. It means that there is an indirect influence that can affect teacher performance other than the endogenous variables that the researchers studied. From the results obtained, it is known that the coefficient of determination is 0.205 or $20.5 \%$. It means that transformational leadership variable (X1) and interpersonal communication (X2) have a simultaneous effect on the teacher performance 
variable $\left(\mathrm{X}_{3}\right)$ by $20.5 \%$. Meanwhile, the other $79.5 \%$ were influenced by other variables which were not researched.

\section{Hypothesis Test}

1) T-Test

Table 9. T-Test

\begin{tabular}{lcc}
\hline \multicolumn{1}{c}{ Variable } & tcount & Sig \\
\hline Transformational Leadership & 2.845 & 0,006 \\
\hline Communication (X2) & 2.479 & 0,015 \\
\hline
\end{tabular}

From the results obtained, transformational leadership (X1) and interpersonal communication (X2) affect teacher performance $\left(\mathrm{X}_{3}\right)$ partially. This is evident from the significant value of each independent variable. This significance of the transformational leadership variable is o.006, which is smaller $(<)$ than 0.05. In addition, the t-count value for the transformational leadership variable is 2.845 greater $(>)$ than t-table 1.665 . It can be concluded that transformational leadership (X1) affects teacher performance $\left(\mathrm{X}_{3}\right)$. Interpersonal communication (X2) with the value of 0.015 is also smaller $(<)$ than 0.05 . The t-observed of interpersonal communication variable is 2.479 greater $(>)$ than t-table 1.665. It shows a positive influence between work environment and performance.

2) F-Test

Table 10. F-Test

\begin{tabular}{llcrcrc}
\hline Model & & $\begin{array}{c}\text { Sum of } \\
\text { Squares }\end{array}$ & df & $\begin{array}{c}\text { Mean } \\
\text { Square }\end{array}$ & F & Sig. \\
\hline 1 & Regressio & 1659.222 & 2 & 829.611 & 9.686 & .000 $^{\mathrm{b}}$ \\
& $\mathrm{n}$ & & & & & \\
& Residual & 6424.073 & 75 & 85.654 & & \\
\hline & Total & 8083.295 & 77 & & & \\
\hline
\end{tabular}

a. Dependent Variable: Performance $\left(\mathrm{X}_{3}\right)$

b. Predictors: (Constant), Communication (X2), Transformation Leadership (X1)

From the table above, it can be seen that transformational leadership and interpersonal communication affect teachers' performance simultaneously. It can be seen from the significance value (Sig.), which is equal to 0.000 , which is smaller $(<)$ than 0.05 . In addition, conclusions can be drawn by looking at the F-observed value of 9.686 is greater $(>)$ than F-table 3.12. From these results, it can be stated that transformational leadership and interpersonal communication simultaneously affect teachers' performance.

The data above shows that each variable has a positive and significant influence. It can be seen based on the results of the t-test and F-test. The researchers got the results of the t-test with transformational leadership variables ( X1) on Teacher Performance (Y) with a t-count of 2.845 and t-table of 1.665 , meaning that $\mathrm{Ho}$ is rejected and $\mathrm{H} 1$ is accepted. It shows that the transformational leadership variable has a positive influence on teacher performance. Another thing in line with the results of this study is the similarity with the results of research conducted by Kurniawati et al. (2017). The results of this study obtained t-count for the transformational leadership variable of 5,427 and t-table of 2,005, which means t-count is greater than t-table. It means that H1 is accepted. The conclusion is that transformational leadership has a significant effect on teachers performance. The results of other studies are also supported by Akbar et al. (2019) based on the F-count obtained by 56.270 , which is greater than F-table of 4.03 , then $\mathrm{Ho}$ is rejected, and $\mathrm{H} 1$ is accepted, so there is a positive and significant influence between the transformational leadership variable (X1) on teacher performance. This is under the results of the F-test calculation that the researcher did. For the results of the F test, the F-count value of 9.686 is greater than F-table of 3.12, then Ho is rejected and H1 is accepted. It means that there is a positive and significant influence between transformational leadership on teacher performance. In addition, it is also supported by the result of another study Makena (2017), obtaining a t-count of 5.037 > 1.99 and a significant value of $0.445>0.05$, meaning that transformational leadership has a positive and significant effect on performance. This is in line 
with experts who state that leadership can influence a group toward achieving a vision or set of goals. Robbins \& Judge (2013) found the leadership must be able to influence a group towards achieving a vision or set of goals. As a principal, he/she must be able to provide direction to teachers well and carry out stimuli that inspire teachers in carrying out their duties.

Research conducted by Kurniawati et al. (2017) proves an effect of the principal's transformational leadership and school organisational climate on teacher performance, with a correlation coefficient of 0.813 and a coefficient of determination of 0.660 . These results explain that the higher the level and transformational, the higher the teacher performance level. Von Glinow \& McShane (2010) found that transformational leadership views leaders as agents of change. They create, communicate and create a shared vision for a team or organisation. They encourage experimentation so that employees find better paths for the future. Through these and other activities, transformational leadership also builds the commitment of its followers to strive for the vision.

Meanwhile, the influence of interpersonal communication on performance has a direct effect of 0.070. An indirect effect of 0.021 between interpersonal communication variables (X2) on teacher performance $(\mathrm{Y})$, for the t-count results obtained, is 2.479, greater than T-table of 1.665. Ho is rejected, and $\mathrm{H} 1$ is accepted, meaning a positive influence between interpersonal communication variables on teacher performance. Different things are proven based on the results of research conducted by Diana et al. (2020). The results of the calculation of the t-test obtained are 0.72, which is smaller than the t-table of 1.668, then Ho is accepted, and H1 is rejected, meaning that there is no significant effect on teacher performance. These things are in line with the results of research conducted by Ritonga (2019). Based on the results of linear regression calculations, it is obtained that $\mathrm{Y}=72.836+0.658 \mathrm{X}$, the significant value of the Anova test results obtained is 0.000 where this value is smaller than 0.05 , meaning that interpersonal communication has a positive influence on teacher performance. This research is also supported by research results Nilasari \& Fitria (2020). The hypothesis testing t-test and f-test get a t-count of 3.291 and a t-table of 1.671 with a significant level of $0.002<0.05$. It indicates Ho is rejected and $\mathrm{H}_{1}$ is accepted, meaning that there is a positive and significant influence between interpersonal communication variables on performance. It is in line with the results of research from Kartini et al. (2020). The study results show a positive and significant influence with a significant value of $0.000<0.05$, meaning that Ho is rejected, then there is a significant influence of interpersonal communication on teacher performance at the State Junior High School 3 Sanga. According to Colquitt et al. (2017), the elements of communication include encoding the message as information by the sender and the message being translated by the recipient into understanding after the process of sending the message through interference or noise.

\section{CONCLUSION}

This study provides a positive and significant influence, both independent and dependent variables. It can be seen from the positive influence of transformational leadership on teachers' performance $\left(\mathrm{X}_{3}\right)$, the positive influence of interpersonal communication (X2) on teachers' performance $\left(\mathrm{X}_{3}\right)$ and the positive and significant influence of leadership variables (X1). Simultaneous interpersonal communication (X2) on the teachers' performance ( $\left.\mathrm{X}_{3}\right)$ at The State Vocational High School of East Jakarta II teachers. Based on these results, the principal must pay special attention to interpersonal communication to school teachers to maintain the quality of teacher performance. Besides that, the principal must be a role model with positive values related to their functional role to all stakeholders in the school. At the same time, teachers must also maintain a two-way relationship, both interpersonal communication between fellow teachers and communication to superiors. In this study, the researchers were aware of weaknesses and shortcomings, both writing and limited results. Writers hope that the results of this study can be used as a reference for researchers who will take similar study or research areas or can be added with other variables. 
Akbar, L., Imaniyati, N., Setiabudhi, J., Bandung, N., \& Indonesia, J. B. (2019). Gaya kepemimpinan transformasional kepala sekolah terhadap kinerja guru ( Principal transformational leadership style to teacher performance). 4(2). https://doi.org/10.17509/jpm.v4i2.18012

Colquitt, J. A., Lepine, J. A., \& Wesson, M. J. (2017). Organisational Behavior: Improving performance and commitment in the workplace. In Practice Development in Health Care (Sixth Edit, Vol. 4, Issue 4). McGraw-Hill. https://doi.org/10.1002/pdh.22

Crede, M., Jong, J., \& Harms, P. (2019). The generalizability of transformational leadership across cultures: a meta-analysis. Journal of Managerial Psychology, 34(3), 139-155. https://doi.org/10.1108/JMP-11-2018-0506

Diana, R., Ahmad, S., \& Wahidy, A. (2020). Pengaruh Motivasi Kerja dan Komunikasi Interpersonal Terhadap Kinerja Guru. Jurnal Pendidikan Tambusai, 4, 1828-1835.

Doh,J.P.,S.A. Stumpf and W.G.Tymon.2011).Responsible leadership helps retain talent,vol.98. India: Journal of Bussiness Ethics.

Jalalkamali, M., Ali, A. J., Hyun, S. S., \& Nikbin, D. (2016). Relationships between work values, communication satisfaction, and employee job performance: The case of international joint ventures in Iran. Management Decision, 54(4), 796-814. https://doi.org/10.1108/MD-012015-0003

Jyoti, J., \& Bau, S. (2015). Transformational Leadership and job performance: A Study of Higher education. February 2017, 2014-2015.

Kartini, K., Ahmad, S., \& Eddy, S. (2020). Pengaruh Gaya Kepemimpinan Kepala Sekolah dan Komunikasi Interpersonal Terhadap Kinerja Guru. Journal of Education Research, 1(3), 290294.

Kurniawati, S., Sukmawati, \& Chiar, M. (2017). Pengaruh Kepemimpinan Transformasional Kepala Sekolah Dan Iklim Organisasi Sekolah Terhadap Kinerja Guru. 1-12. https://jurnal.untan.ac.id/index.php/jpdpb/article/view/18350/15489

Makena, J. E. (2017). organisasi di Hotel Prama Sanur Beach belajaran organisasi di Hotel Prama ganisasi di Hotel Prama Sanur Beach terhadap kinerja organisasi di Hotel hadap inovasi pada Hotel Prama Sanur Beach Bali? Kerangka Konseptual. 4(2). https://doi.org/10.22225/jj.4.2.135.76-88

Masa'deh, R., Obeidat, B. Y., \& Tarhini, A. (2016). A Jordanian empirical study of the associations among transformational leadership, transactional leadership, knowledge sharing, job performance, and firm performance. Journal of Management Development, 35(5), 681-705. https://doi.org/10.1108/JMD-09-2015-0134

Nilasari, S., \& Fitria, H. (2020). Pengaruh Komunikasi Interpersonal dan Disiplin Kerja terhadap kinerja guru. 2(3).

Ocham, L., \& Okoth, U. A. (2015). Head-teachers' motivational practices in public secondary schools in Kenya. TQM Journal, 27(6), 814-822. https://doi.org/10.1108/TQM-08-2015-0110

Ritonga, B. (2019). Pengaruh Komunikasi Interpesonal, Gaya Kepemimpinan, Budaya organisasi terhadap kinerja guru di MAN 2 Model. 246-257.

Robbins, S. P., \& Judge, T. A. (2013). Organisational Behavior (15th editi). Pearson. https://doi.org/10.1007/BFo1148546

Robbins, S. P., \& Judge, T. A. (2017). Organisational Behavior, Seventeenth Edition, Global Edition. Pearson Education Limited, 747.

Sugiyono. (2017). Metode Penelitian Kuantatif, Kualitatif, dan R\&D.

Von Glinow, M. A., \& McShane, S. L. (2010). Organisational Behavior (5th Editio). McGraw-Hill.

Yang, C. L., \& Hwang, M. (2014). Personality traits and simultaneous reciprocal influences between job performance and job satisfaction. Chinese Management Studies, 8(1), 6-26. https://doi.org/10.1108/CMS-09-2011-0079

Yukl, G. A. (2013). Leadership in organisations (Global ed.). In Essex: Pearson (Global Edi). Pearson. 